\title{
Enantioselective solvent-free Robinson annulation reactions
}

\author{
D RAJAGOPAL, R NARAYANAN and S SWAMINATHAN* \\ Department of Organic Chemistry, University of Madras, Guindy Campus, \\ Chennai 600 025, India \\ e-mail: samaswami@yahoo.com
}

MS received 28 March 2001

\begin{abstract}
The enantioselective cyclization of the prochiral cyclic substrates 1 to 7 and 26, can be carried out in the neat using $S$-proline as catalyst. The substrates $\mathbf{1 8}$ to 22 and 27 could not be cyclized with $S$-proline but could be cyclized with a mixture of $S$-phenylalanine and $d$-camphorsulphonic acid. The enantioselective cyclization of prochiral acyclic triones $\mathbf{4 5}$ and $\mathbf{4 7}$ and also the racemic tricarbonyl compounds $\mathbf{5 4}$ to 57 could also be carried out in the neat using $S$-proline as catalyst. The optically active enediones obtained in the above cyclizations could also be obtained directly from 1,3-diones or 2-hydroxymethylene cycloalkanones in a one-pot reaction with methyl vinyl ketone (MVK) and $S$-proline in the absence of solvents. ${ }^{13} \mathrm{C}$ NMR studies of the one-pot synthesis of $\mathbf{S - 1 1}$ and $\mathbf{S - 1 4}$ reveal that the annulations involve initial formation of an acid-base complex followed by a Michael reaction and then an enantioselective cyclization. Such enantioselective cyclizations probably occur on the surface of $S$-proline crystals.
\end{abstract}

Keywords. Enantioselective annulation; cyclization; $S$-proline; $S$-phenylalanine; $d$-camphorsulphonic acid.

\section{Introduction}

Robinson annulation reactions have a distinct place in synthetic organic chemistry because of their ability to provide a four-carbon chain in a single step leading to annulated carbocyclic molecules ${ }^{1}$. The use of proline or any other amino acid in asymmetric annulation reactions in a solid-liquid phase reaction in the absence of solvents to effect an asymmetric synthesis is an important step forward towards cleaner synthesis ${ }^{2}$. Environmental and economic pressures are now forcing the chemical community to search for more efficient ways of performing chemical transformations. With asymmetric synthesis so much to the fore in current thinking, it is important to seek chiral transfer reactions that can operate neat.

Reports on solvent-free reactions have become increasingly frequent and the field has developed into an important branch of 'Green chemistry' ${ }^{3}$. Such solvent-free reactions include reactions between solids ${ }^{4}$, between gases and solids and non-supporting inorganic reagents. In continuation of our preliminary communication ${ }^{2}$, we wish to present more comprehensively here our results on enantioselective Robinson annulation

Based on a lecture delivered by S Swaminathan on 3 February 2001 at the National Symposium in Chemistry organized by the Chemical Research Society of India at Chandigarh.

*For correspondence 
reactions. The diketones S-11 and S-14 are potential chiral synthons for the synthesis of steroids, terpenes and natural products ${ }^{5,6}$. These diketones can be obtained by asymmetric cyclization using $S$-proline, as reported ${ }^{2}$ by us in the absence of solvents of prochiral triones 1 and 4 respectively. With a view to extend the scope of such solvent-free reactions, we have studied the enantioselective cyclization of three different types of substrates viz.,

(i) prochiral cyclic, (ii) prochiral acyclic and (iii) racemic substrates.<smiles>[R]C1(CCC(C)=O)C=C(C)C(=O)C1=O</smiles>

$$
n=1, \mathrm{R}=\mathrm{CH}_{3} ; \mathbf{1}
$$

$n=1, \mathrm{R}=\mathrm{C}_{2} \mathrm{H}_{5} ; 2$

$n=1, \mathrm{R}=\mathrm{SPh} ; \mathbf{3}$

$n=2, \mathrm{R}=\mathrm{CH}_{3} ; 4$

$n=2, \mathrm{R}=\mathrm{C}_{2} \mathrm{H}_{5} ; \mathbf{5}$

$n=2, \mathrm{R}=\mathrm{CH}_{2} \mathrm{CH}_{2} \mathrm{COCH}_{3} ; \mathbf{6}$

$n=2, \mathrm{R}=\mathrm{SPh} ; 7$

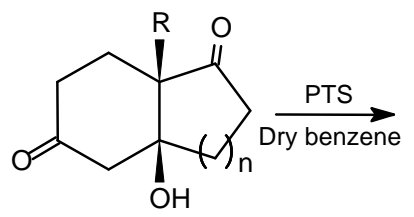<smiles>[R][C@]12CCC(=O)C=C1CCC2=O</smiles>

$\mathrm{R}=\mathrm{CH}_{3} ; \mathbf{8}$

$\mathrm{R}=\mathrm{C}_{2} \mathrm{H}_{5} ; 9$

$\mathrm{R}=\mathrm{CH}_{3} ; \mathbf{S}-\mathbf{1 1}$

$\mathrm{R}=\mathrm{C}_{2} \mathrm{H}_{5} ; \mathrm{S}-12$

$\mathrm{R}=\mathrm{SPh} ; \mathbf{R}-13$

$\mathrm{R}=\mathrm{CH}_{3} ; \mathbf{S}-14$

$\mathrm{R}=\mathrm{C}_{2} \mathrm{H}_{5} ;( \pm)-\mathbf{1 5}$

$\mathrm{R}=\mathrm{CH}_{2} \mathrm{CH}_{2} \mathrm{COCH}_{3} ; \mathbf{S}-\mathbf{1 6}$

$\mathrm{R}=\mathrm{SPh} ; \mathbf{R}-17$

Scheme 1. Cyclization using $S$-proline as a chiral auxiliary.

Table 1. Cyclizations using $S$-proline.

\begin{tabular}{|c|c|c|c|c|c|c|c|c|c|}
\hline $\begin{array}{l}\text { Subst- } \\
\text { srate }\end{array}$ & $\begin{array}{l}\text { Wt. }(\mathrm{g}) \\
\text { of } \\
\text { substrate } \\
(\mathrm{mol})\end{array}$ & $\begin{array}{l}\text { Proline } \\
S / R\end{array}$ & $\begin{array}{l}\text { Wt. (g) of } \\
\text { proline } \\
\text { (mol) }\end{array}$ & $\begin{array}{c}\text { Time } \\
(h)\end{array}$ & $\begin{array}{c}\text { Temp. } \\
\left({ }^{\circ} \mathrm{C}\right)\end{array}$ & Product & {$[\alpha]_{D}^{25}$} & $\begin{array}{l}\text { ele } \\
(\%)\end{array}$ & $\begin{array}{c}\text { Yield } \\
(\%)\end{array}$ \\
\hline 1 & $\begin{array}{c}1 \cdot 82 \\
(0 \cdot 01)\end{array}$ & $S$ & $\begin{array}{c}0.055 \\
(0 \cdot 0005)\end{array}$ & 88 & $15-20$ & S-11 & $+220.86^{\circ}$ & $60 \cdot 2$ & 66 \\
\hline 1 & $\begin{array}{c}1.82 \\
(0.01)\end{array}$ & $R$ & $\begin{array}{c}0.055 \\
(0.0005)\end{array}$ & 82 & 25 & R-11 & $-272.68^{\circ}$ & $74 \cdot 3$ & 59 \\
\hline 2 & $\begin{array}{c}1.96 \\
(0.01)\end{array}$ & $S$ & $\begin{array}{c}0.055 \\
(0.0005)\end{array}$ & 100 & $22-25$ & S-12 & $+204.36^{\circ}$ & 78 & 68 \\
\hline 3 & $\begin{array}{c}1.0 \\
(0.0038)\end{array}$ & $S$ & $\begin{array}{c}0.02 \\
(0.00019)\end{array}$ & 150 & $18-20$ & R-13 & $+74^{\circ}$ & $64 \cdot 7$ & 33 \\
\hline 4 & $\begin{array}{c}0.98 \\
(0.005)\end{array}$ & $S$ & $\begin{array}{c}0.03 \\
(0.00035)\end{array}$ & 68 & RT & S-14 & $+64 \cdot 7^{\circ}$ & $64 \cdot 7$ & 33 \\
\hline 4 & $\begin{array}{l}1.96 \\
(0.01)\end{array}$ & $R$ & $\begin{array}{c}0.0575 \\
(0 \cdot 0005)\end{array}$ & 70 & RT & R-14 & $-67 \cdot 1^{\circ}$ & $67 \cdot 1$ & 32 \\
\hline 5 & $\begin{array}{l}2 \cdot 10 \\
(0 \cdot 01)\end{array}$ & $S$ & $\begin{array}{c}0.0575 \\
(0.0005)\end{array}$ & 90 & RT & $( \pm)-15$ & 0 & 0 & 52 \\
\hline 6 & $\begin{array}{c}2.52 \\
(0.01)\end{array}$ & $S$ & $\begin{array}{c}0.0575 \\
(0 \cdot 0005)\end{array}$ & 65 & RT & S-16 & $+26 \cdot 2^{\circ}$ & $*$ & 48 \\
\hline 7 & $\begin{array}{c}0.800 \\
(0 \cdot 0029)\end{array}$ & $S$ & $\begin{array}{c}0.016 \\
(0 \cdot 00014)\end{array}$ & 140 & 20 & R-17 & $-97.5^{\circ}$ & 50 & 34 \\
\hline
\end{tabular}

*ele not determined 


\section{Cyclization}

\subsection{Cyclization of prochiral cyclic substrates}

The prochiral triketones (scheme 1) were prepared according to the literature method ${ }^{7}$. The cyclizations were carried out under nitrogen atmosphere in the neat ${ }^{2}$. Table 1 gives optimum conditions to get the various products in maximum chemical as well as optical yields. The products were characterized by IR, NMR and mass spectra. Enantiomeric excess of the product was calculated on the basis the know specific rotations of the enantiomerically pure compounds. In the case of cyclopentane derivatives, the initial products were ketols which were dehydrated by refluxing with PTS in dry benzene.

The neat asymmetric cyclization could be extended to other prochiral cyclic triones (18-22) obtained using ethyl vinyl ketones a Michael acceptor (scheme 2). Our attempts to cyclize these triketones using $S$-proline were unsuccessful; however a mixture of $S$ phenylalanine and $d$-camphorsulphonic acid (1:1) was found to effect cyclization in the absence of solvent. The products obtained were characterized by IR and NMR, and ele was calculated for known compounds on the basis of specific rotations reported in the literature. Table 2 gives the optimum conditions for the various cyclizations.

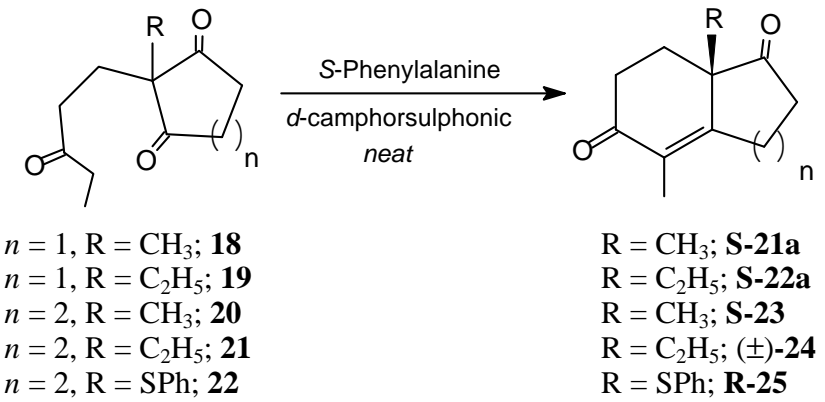

Scheme 2. Cyclization using $S$-phenylalanine and $d$-camphorsulphonic acid mixture.

Table 2. Cyclizations using $S$-phenylalanine and $d$-camphorsulphonic acid mixture.

\begin{tabular}{|c|c|c|c|c|c|c|c|c|c|}
\hline $\begin{array}{l}\text { Subst- } \\
\text { rate }\end{array}$ & $\begin{array}{l}\text { Wt. (g) of } \\
\text { substrate } \\
\text { (mol) }\end{array}$ & $\begin{array}{l}\text { Wt. }(\mathrm{g}) \text { of } \\
S \text {-phenyl- } \\
\text { alanine } \\
(\mathrm{mol})\end{array}$ & $\begin{array}{l}\text { Wt. }(\mathrm{g}) \text { of } \\
d \text {-camphor } \\
\text { sulphonic } \\
\text { acid } \\
(\mathrm{mol})\end{array}$ & $\begin{array}{l}\text { Time } \\
\text { (h) }\end{array}$ & $\begin{array}{c}\text { Temp. } \\
\left({ }^{\circ} \mathrm{C}\right)\end{array}$ & Product & {$[\alpha]_{D}^{25}$} & $\begin{array}{l}\text { ele } \\
(\%)\end{array}$ & $\begin{array}{c}\text { Yield } \\
(\%)\end{array}$ \\
\hline 18 & $\begin{array}{c}1.96 \\
(0.01)\end{array}$ & $\begin{array}{c}1.65 \\
(0.01)\end{array}$ & $\begin{array}{c}1 \cdot 16 \\
(0.005)\end{array}$ & 24 & 80 & S-21a & $+266 \cdot 2^{\circ}$ & 79 & 59 \\
\hline 19 & $\begin{array}{c}1 \cdot 0 \\
(0 \cdot 005)\end{array}$ & $\begin{array}{c}0 \cdot 850 \\
(0 \cdot 005)\end{array}$ & $\begin{array}{c}0.550 \\
(0 \cdot 0025)\end{array}$ & 20 & 73 & S-22a & $+189^{\circ}$ & $*$ & 55 \\
\hline 20 & $\begin{array}{l}2 \cdot 13 \\
(0.01)\end{array}$ & $\begin{array}{l}1.65 \\
(0.01)\end{array}$ & $\begin{array}{c}1 \cdot 16 \\
(0.005)\end{array}$ & 30 & $72-75$ & S-23 & $+114^{\circ}$ & 82 & 53 \\
\hline 21 & $\begin{array}{c}0.550 \\
(0.0025)\end{array}$ & $\begin{array}{c}0.400 \\
(0.0025)\end{array}$ & $\begin{array}{c}0.280 \\
(0.00025)\end{array}$ & 25 & 75 & $( \pm)-24$ & 0 & - & 61 \\
\hline 22 & $\begin{array}{c}3.0 \\
(0.01)\end{array}$ & $\begin{array}{c}1.65 \\
(0.01)\end{array}$ & $\begin{array}{c}1.16 \\
(0.005)\end{array}$ & 22 & 90 & R-25 & $+33^{\circ}$ & $*$ & 48 \\
\hline
\end{tabular}

*ele not determined 
The yields in the above neat cyclization using $S$-phenylalanine and $d$-camphorsulphonic acid are comparable with those obtained ${ }^{8}$ in solvent in at least one case, $\mathbf{S - 2 3}$.

In continuation, we have successfully carried out the neat cyclization of triones of the type $\mathbf{2 6}$ and $\mathbf{2 7}$ obtained from indane 1,3-dione as depicted in scheme 3.

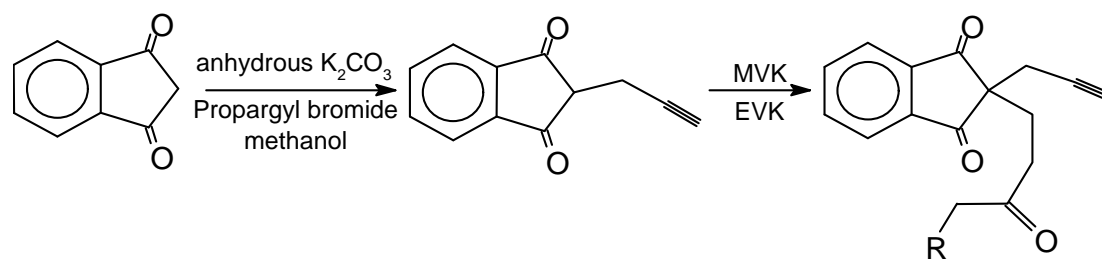

$\mathrm{R}=\mathrm{H} ; 26$

$\mathrm{R}=\mathrm{CH}_{3} ; 27$<smiles>[R]CC(=O)CCC1(CC)C(=O)c2ccccc2C1=O</smiles>

$\mathrm{R}=\mathrm{H}, \mathbf{2 8}$

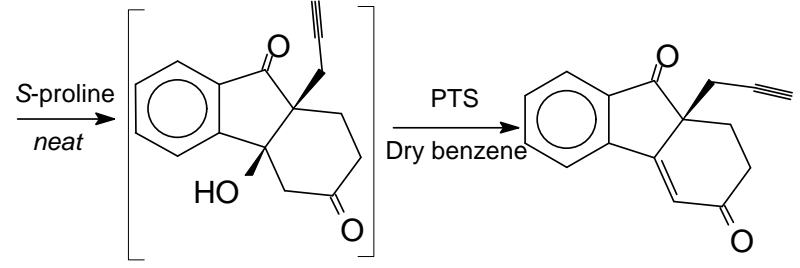

$\mathrm{R}=\mathrm{H}, \mathbf{S}-\mathbf{2 9}$

$\mathrm{R}=\mathrm{CH}_{3} ; \mathbf{S}-\mathbf{3 0}$

Scheme 3. Cyclization of derivatives of indane-1,3-dione.

Table 3. Cyclization of trione-2,6.

\begin{tabular}{|c|c|c|c|c|c|c|c|c|}
\hline Substrate & $\begin{array}{c}\text { Wt. }(g) \text { of } \\
\text { substrate } \\
(\mathrm{mol})\end{array}$ & $\begin{array}{l}\text { Proline } \\
S / R\end{array}$ & $\begin{array}{c}\text { Wt.(g) of } \\
\text { proline } \\
(\mathrm{mol})\end{array}$ & $\begin{array}{c}\text { Time } \\
(h)\end{array}$ & $\begin{array}{c}\text { Temp. } \\
\left({ }^{\circ} \mathrm{C}\right)\end{array}$ & Product & {$[\alpha]_{D}^{25}$} & $\begin{array}{c}\text { Yield } \\
(\%)\end{array}$ \\
\hline 26 & $\begin{array}{c}0.500 \\
(0 \cdot 002)\end{array}$ & $S$ & $\begin{array}{c}0.040 \\
(0.00034)\end{array}$ & 58 & RT & S-29 & $+112^{\circ}$ & 58 \\
\hline 26 & $\begin{array}{c}0.500 \\
(0.002)\end{array}$ & $\mathrm{R}$ & $\begin{array}{c}0.230 \\
(0.002)\end{array}$ & 60 & RT & R-29 & $-112 \cdot 1^{\circ}$ & 62 \\
\hline
\end{tabular}

The compound S-29 has been used for the synthesis of the Gibbane framework by Takano et $a l^{9}$. The literature method of preparation of S-29 involves cyclization of propargyl trione 26, using $S$-proline as chiral auxiliary in $\mathrm{N}, \mathrm{N}$-dimethylformamide. The same cyclization could be carried out using $S$-proline in the neat under nitrogen atmosphere. The results are summarized in table 3 . The reaction was also performed using pyrrolidine/acetic acid in dry ether at lower temperature. The racemic diketone $( \pm)-$ 29 was characterized by IR, NMR and mass spectra and further confirmed by X-ray analysis ${ }^{10}$. 
Our attempts to cyclize the trione 27 using proline were unsuccessful. Instead a combination of $S$-phenylalanine and $d$-camphorsulphonic acid was found to be effective in bringing about cyclization of trione $\mathbf{2 7}$ to $\mathbf{S - 3 0}$. The compound $\mathbf{S - 3 0}$ was characterized by IR, NMR and mass spectral data.

The cyclization of triones obtained from cyclopentane and cyclohexane 1,3-diones has prompted us to investigate the triones derived from cycloheptane 1,3-dione ${ }^{11}$ (scheme 4).

This dione was treated with methyl/ethyl iodide in the presence of potassium $t$ butoxide in $t$-butanol or alternatively with DBU/anhydrous LiI and alkali iodide in dry THF maintained at $65-70^{\circ} \mathrm{C}$. The 2-alkyl cycloheptane-1,3-diones were obtained in $92-$ $95 \%$ yield (based on recovered starting dione).

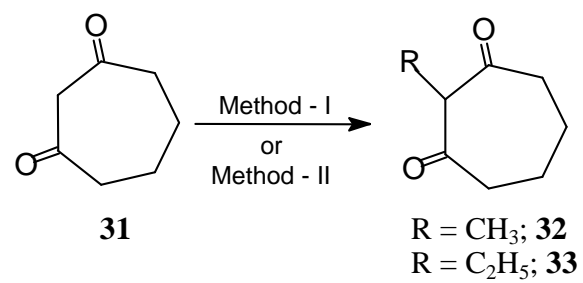

Method I: Potassium $t$-butoxide/t-butanol/ $\mathrm{CH}_{3}$ or $\mathrm{C}_{2} \mathrm{H}_{5}$ at $60-65^{\circ} \mathrm{C}$ Method II: DBU-anhydrous $\mathrm{LiI} / \mathrm{CH}_{3}$ or $\mathrm{C}_{2} \mathrm{H}_{5}$ in dry THF at $60^{\circ} \mathrm{C}$.

Our attempts to cyclize triones 37, 39, 41 and 43 (scheme 4) using either proline or a combination of $S$-phenylalanine and $d$-camphorsulphonic acid did not yield the expected optical-active products either in solvent or under neat condition. Surprisingly, however, cyclization of the same trione could be done using pyrrolidine/acetic acid in dry ether to give the corresponding $d l$ products 38, 40, 42 and 44 in $60-65 \%$ chemical yield. The structures were confirmed by IR, NMR and mass spectra. The structure of trione $\mathbf{3 9}$ and diketone $( \pm)-\mathbf{4 0}$ were further confirmed by $\mathrm{X}$-analysis ${ }^{12}$.

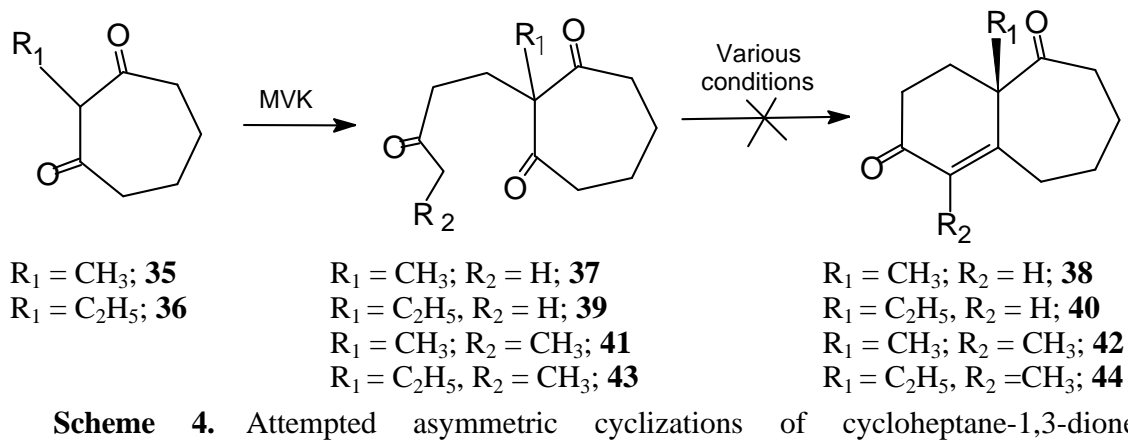
derivatives.

\subsection{Cyclization of prochiral acyclic substrates}

Next, it was of interest to study the neat cyclization of some prochiral acyclic substrates (scheme 5). 3-Acetyl-3-methyl-2,6-heptane-dione (45) and 3-acetyl-ethyl-2,6-heptanedione (47) were easily obtained by literature methods as liquids. These triones on 
<smiles>[R]C(CCC(C)=O)(C(C)=O)C(C)=O</smiles>

$$
\begin{array}{ll}
\mathrm{R}=\mathrm{CH}_{3} ; \mathbf{4 5} & \mathrm{R}=\mathrm{CH}_{3} ; \mathbf{R}-\mathbf{4 6} \\
\mathrm{R}=\mathrm{C}_{2} \mathrm{H}_{5} ; \mathbf{4 7} & \mathrm{R}=\mathrm{C}_{2} \mathrm{H}_{5} ; \mathbf{R}-\mathbf{4 8}
\end{array}
$$

Scheme 5. Cyclizations of triones $\mathbf{4 5}$ and $\mathbf{4 7 .}$

treatment with $S$-proline under nitrogen atmosphere at $50-55^{\circ} \mathrm{C}$ gave the cyclized products R-46 and R-48 respectively. IR and NMR data confirmed the structures; the stereochemistry of R-46 was deduced by comparison of rotation with the product obtained earlier using solvent. The configuration of $\mathbf{R}-\mathbf{4 8}$ is assumed by analogy to R-46.

The reaction conditions used are tabulated in table 4. As far as the above acyclic substrates are concerned, the neat technique seems inferior to the reported solventmediated cyclization ${ }^{13}$.

\subsection{Cyclization of racemic subtrates}

In further studies of our neat techniques, attention was focussed on $S$-proline mediated cyclization of racemic tricarbonyl compounds of type $\mathbf{5 4}$ (scheme 6). These cyclizations must involve kinetic resolution; one of the two possible diastereoisomers with $S$-proline must be reacting faster than the other. The required starting materials namely 2hydroxymethylene cycloalkanones and its Michael adducts were prepared according to literature procedures ${ }^{14}$.
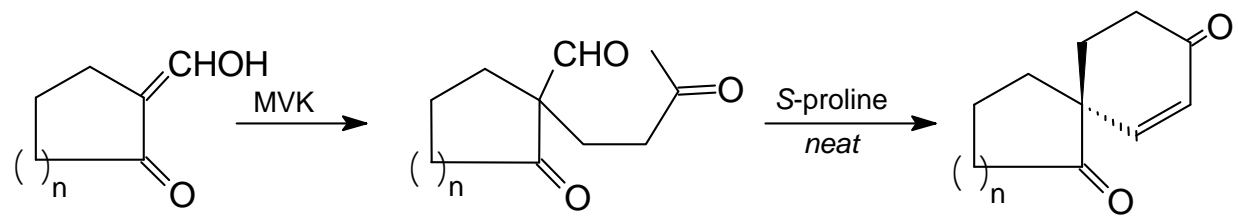

$n=1, \mathbf{4 9}$
$n=2, \mathbf{5 0}$
$n=3, \mathbf{5 1}$
$n=4, \mathbf{5 2}$
$n=8, \mathbf{5 3}$

$( \pm)-54$

$( \pm)-55$

$( \pm)-56$

$( \pm)-57$

$( \pm)-58$
S-59

S-60

S-61

S-62

$( \pm)-63$

Scheme 6. Asymmetric cyclizations of racemic triones. 
Table 4. Cyclisation of triones $\mathbf{4 5}$ and $\mathbf{4 7}$.

\begin{tabular}{|c|c|c|c|c|c|c|c|c|c|}
\hline Substrate & $\begin{array}{l}\text { Wt. (g) of } \\
\text { substrate } \\
(\mathrm{mol})\end{array}$ & $\begin{array}{l}\text { Proline } \\
S / R\end{array}$ & $\begin{array}{l}\text { Wt. (g) of } \\
\text { proline } \\
\text { (mol) }\end{array}$ & $\begin{array}{l}\text { Time } \\
\text { (h) }\end{array}$ & $\begin{array}{c}\text { Temp. } \\
\left({ }^{\circ} \mathrm{C}\right)\end{array}$ & Product & {$[\alpha]_{D}^{25}$} & $\begin{array}{l}\text { ele } \\
(\%)\end{array}$ & $\begin{array}{l}\text { Yield } \\
(\%)\end{array}$ \\
\hline 45 & $\begin{array}{c}184 \\
(0 \cdot 01)\end{array}$ & $S$ & $\begin{array}{c}1 \cdot 15 \\
(0 \cdot 01)\end{array}$ & 50 & 50 & R-46 & $+20 \cdot 2^{\circ}$ & 12 & 42 \\
\hline 45 & $\begin{array}{c}1.84 \\
(0.01)\end{array}$ & $R$ & $\begin{array}{c}0.060 \\
(0.0005)\end{array}$ & 55 & 60 & S-29 & $-5 \cdot 3^{\circ}$ & $3 \cdot 1$ & 43 \\
\hline 47 & $\begin{array}{c}1.98 \\
(0.01)\end{array}$ & $S$ & $\begin{array}{c}1 \cdot 15 \\
(0.01)\end{array}$ & 52 & 52 & R-48 & $+9^{\circ}$ & $*$ & 45 \\
\hline
\end{tabular}

*ele not determined

Table 5. Asymmetric cyclization of racemic triones.

\begin{tabular}{|c|c|c|c|c|c|c|c|c|c|}
\hline Substrate & $\begin{array}{l}\text { Wt. of }(\mathrm{g}) \\
\text { substrate } \\
\quad(\mathrm{mol})\end{array}$ & $\begin{array}{l}\text { Proline } \\
\text { S/R }\end{array}$ & $\begin{array}{l}\text { Wt. of (g) } \\
\text { proline } \\
(\mathrm{mol})\end{array}$ & $\begin{array}{l}\text { Time } \\
\text { (h) }\end{array}$ & $\begin{array}{l}\text { Temp } \\
\left({ }^{\circ} \mathrm{C}\right)\end{array}$ & Product & {$[\alpha]_{D}^{25}$} & $\begin{array}{l}\text { ele } \\
(\%)\end{array}$ & $\begin{array}{c}\text { Yield } \\
(\%)\end{array}$ \\
\hline 54 & $\begin{array}{c}1.82 \\
(0.01)\end{array}$ & $S$ & $\begin{array}{c}0.057 \\
(0.005)\end{array}$ & 90 & RT & S-59 & $+4.8^{\circ}$ & 29 & 47 \\
\hline 54 & $\begin{array}{c}2.8 \\
(0.015)\end{array}$ & $R$ & $\begin{array}{c}0.090 \\
(0.0007)\end{array}$ & 68 & RT & R-59 & $-4.62^{\circ}$ & 28 & 39 \\
\hline 55 & $\begin{array}{c}4.0 \\
(0.02)\end{array}$ & $S$ & $\begin{array}{c}0.120 \\
(0.001)\end{array}$ & 40 & RT & S-60 & $+3 \cdot 19^{\circ}$ & $39 \cdot 8$ & 58 \\
\hline 56 & $\begin{array}{c}4.2 \\
(0.02)\end{array}$ & $S$ & $\begin{array}{c}0.115 \\
(0.001)\end{array}$ & 136 & RT & S-61 & $+1 \cdot 17^{\circ}$ & $3 \cdot 5$ & 55 \\
\hline 56 & $\begin{array}{c}3.5 \\
(0.016\end{array}$ & $R$ & $\begin{array}{c}0.095 \\
(0.00083)\end{array}$ & 72 & RT & S-61 & $-4 \cdot 17^{\circ}$ & $12 \cdot 3$ & 53 \\
\hline 57 & $\begin{array}{c}2.62 \\
(0.0117)\end{array}$ & $S$ & $\begin{array}{c}0.067 \\
(0.00058)\end{array}$ & 72 & RT & S-62 & $+31 \cdot 2^{\circ}$ & $*$ & 52 \\
\hline 58 & $\begin{array}{c}4.2 \\
(0.015)\end{array}$ & $S$ & $\begin{array}{c}0.230 \\
(0.002)\end{array}$ & 140 & RT & $( \pm)-63$ & 0 & 0 & 92 \\
\hline
\end{tabular}

*ele not determined

The cyclization of the Michael adducts $( \pm)-\mathbf{5 4}-( \pm)-\mathbf{5 8}$ was carried out by stirring with $S$-proline in the neat at room temperature under nitrogen atmosphere. The results of different experiments are summarized in table 5.

The tricarbonyl compound ( \pm )-58-cyclododecanone derivative is a solid with $\mathrm{mp}$. 89$90^{\circ} \mathrm{C}$. It was of particular interest to attempt its neat asymmetric cyclization with $S$ proline - another solid; if successful, it would be the first example of chiral transfer in the solid state using a chiral auxiliary. The neat experiment was repeated a number of times with care taken to ensure thorough mixing of the two reactants using small glass beads. The product isolated turned out to be $( \pm)-63$ in addition to recovered tricarbonyl compound and it was identical in all respects to the authentic sample prepared by NaOEt catalyzed cyclization of $( \pm)-58$. The anomalous behaviour of the tricarbonyl compound $( \pm)-58$ is probably due to the more flexible geometry of the 12-membered ring, levelling the energy difference between the diastereoisomers with proline and leading to equal rates of cyclization. 


\section{One-pot synthesis of optically active Wieland-Miescher ketones and similar} enones in the neat

Earlier we reported ${ }^{15}$ that either of the enantiomers S-60 or R-60 can be obtained from formylcyclohexanone by one-step and two-step processes using the same chiral auxiliary. The enantioselectivity was reversed in the above reaction when $R$-proline was used instead of $S$-proline. It was tempting therefore to extend the above one-step methodology to the synthesis of R-11 using $S$-proline itself since such a process, if successful, will be less expensive than the literature procedure. This expectation did not materialize; instead a convenient one-pot synthesis of $\mathbf{S - 1 1}$ resulted, in contrast to the literature procedure.

This procedure involves a two-step process in which the Michael adduct is prepared first and then cyclodehydrated. In the one-pot procedure, dione $\mathbf{6 4}$ and $S$-proline are stirred together for $30 \mathrm{~min}$ at $15-20^{\circ} \mathrm{C}$ followed by the addition of methylvinylketone (MVK) under nitrogen atmosphere. The stirring is continued for several hours (table 6). The reaction could be carried out both in solvent medium as well as in the neat. After the stated period, the crude ketone without further purification, was dehydrated by treatment with PTS in dry benzene. After usual work up and purification, pure diketone S-11 was obtained. The enantiomeric excess was calculated on the basis of the specific rotation of $100 \%$ pure enantiomer ${ }^{7}$. The one-pot synthesis was extended to the cyclization of other
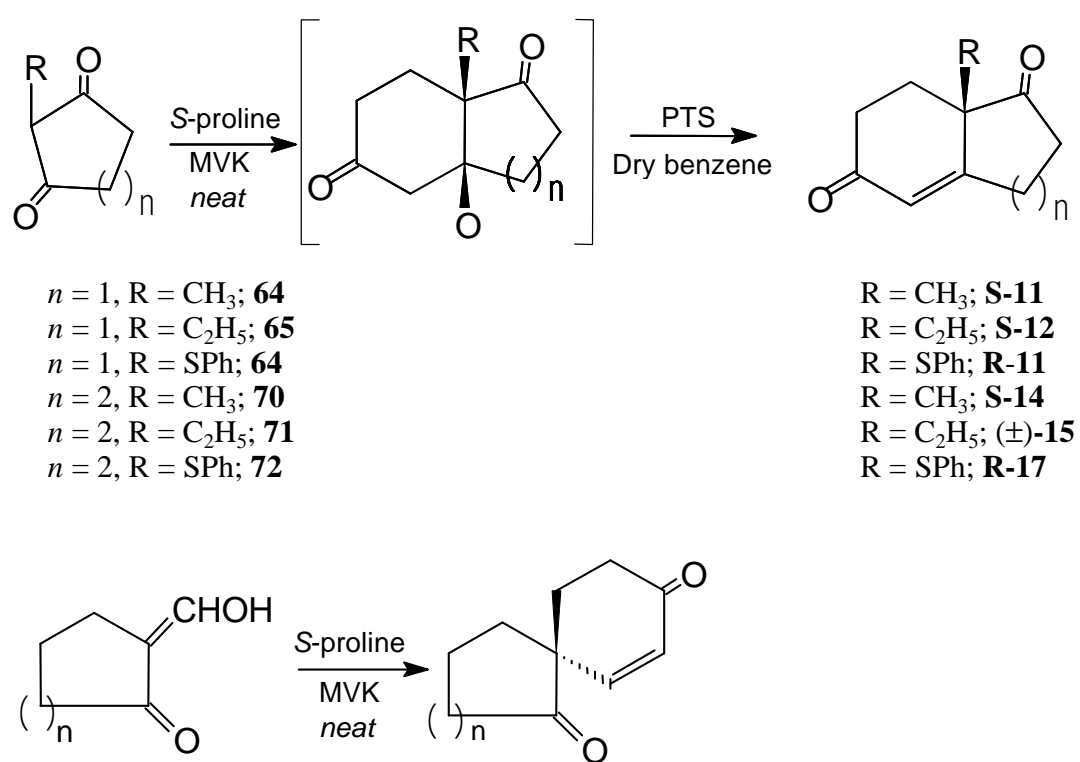

$$
\begin{aligned}
& n=1, \mathbf{4 9} \\
& n=2, \mathbf{5 0} \\
& n=3, \mathbf{5 1} \\
& n=4, \mathbf{5 2} \\
& n=8, \mathbf{5 3}
\end{aligned}
$$

$$
\begin{aligned}
& n=1, \mathbf{S}-59 \\
& n=2, \mathbf{R}-60 \\
& n=3, \mathbf{S}-61 \\
& n=4, \mathbf{S}-62 \\
& n=8,( \pm)-63
\end{aligned}
$$

Scheme 7. One-pot synthesis of chiral enones. 
Table 6. One-pot synthesis of chiral enones.

\begin{tabular}{|c|c|c|c|c|c|c|c|c|c|}
\hline Substrate & $\begin{array}{l}\text { Wt. (g) of } \\
\text { substrate } \\
\text { (mol) }\end{array}$ & $\begin{array}{l}\text { Wt. (g) of } \\
\text { MVK } \\
\text { (mol) }\end{array}$ & $\begin{array}{l}\text { Proline } \\
S / R\end{array}$ & $\begin{array}{l}\text { Wt. (g) of } \\
\text { proline } \\
\text { (mol) }\end{array}$ & $\begin{array}{l}\text { Time } \\
(\mathrm{h})\end{array}$ & $\begin{array}{l}\text { Temp. } \\
\left({ }^{\circ} \mathrm{C}\right)\end{array}$ & Product & $\begin{array}{l}\text { ele } \\
(\%)\end{array}$ & $\begin{array}{l}\text { Yield } \\
(\%)\end{array}$ \\
\hline 49 & $\begin{array}{c}2 \cdot 8 \\
(0 \cdot 025)\end{array}$ & $\begin{array}{c}2 \cdot 1 \\
(0 \cdot 03)\end{array}$ & $S$ & $\begin{array}{c}2 \cdot 87 \\
(0 \cdot 025)\end{array}$ & 82 & RT & S-59 & $27 \cdot 2$ & 48 \\
\hline 50 & $\begin{array}{c}5 \cdot 0 \\
(0.039)\end{array}$ & $\begin{array}{c}2 \cdot 8 \\
(0 \cdot 04)\end{array}$ & $S$ & $\begin{array}{c}4.56 \\
(0.039)\end{array}$ & 82 & RT & R-60 & $33 \cdot 8$ & 49 \\
\hline 51 & $\begin{array}{l}1.40 \\
(0.01)\end{array}$ & $\begin{array}{c}1.05 \\
(0.015)\end{array}$ & $S$ & $\begin{array}{c}1 \cdot 15 \\
(0 \cdot 01)\end{array}$ & 70 & RT & S-61 & $9 \cdot 3$ & 47 \\
\hline 52 & $\begin{array}{c}4.0 \\
(0.025)\end{array}$ & $\begin{array}{c}2 \cdot 1 \\
(0 \cdot 030)\end{array}$ & $S$ & $\begin{array}{c}2 \cdot 875 \\
(0 \cdot 025)\end{array}$ & 70 & RT & S-62 & $(*)$ & $52^{\mathrm{a}}$ \\
\hline 53 & $\begin{array}{c}2 \cdot 10 \\
(0 \cdot 01)\end{array}$ & $\begin{array}{c}0.875 \\
(0 \cdot 0125)\end{array}$ & $S$ & $\begin{array}{c}0.0575 \\
(0 \cdot 0005)\end{array}$ & 110 & RT & $( \pm)-63$ & 0 & 63 \\
\hline 64 & $\begin{array}{c}1 \cdot 12 \\
(0 \cdot 01)\end{array}$ & $\begin{array}{c}2.5 \\
(0.035)\end{array}$ & $S$ & $\begin{array}{c}1.15 \\
(0.01)\end{array}$ & 170 & $15-20$ & S-11 & $48 \cdot 8$ & 24 \\
\hline 65 & $\begin{array}{c}1 \cdot 26 \\
(0 \cdot 01)\end{array}$ & $\begin{array}{c}1 \cdot 2 \\
(0 \cdot 017)\end{array}$ & $S$ & $\begin{array}{c}1 \cdot 15 \\
(0 \cdot 01)\end{array}$ & 100 & $12-20$ & S-12 & $65 \cdot 5$ & 34 \\
\hline 66 & $\begin{array}{l}1.26 \\
(0.01)\end{array}$ & $\begin{array}{c}2.5 \\
(0.035)\end{array}$ & $S$ & $\begin{array}{l}1 \cdot 15 \\
(0.01)\end{array}$ & 50 & RT & S-14 & $43 \cdot 8$ & 25 \\
\hline 71 & $\begin{array}{l}1.28 \\
(0.01)\end{array}$ & $\begin{array}{c}1.4 \\
(0.02)\end{array}$ & $S$ & $\begin{array}{l}1 \cdot 15 \\
(0 \cdot 01)\end{array}$ & 105 & RT & $( \pm)-15$ & 0 & $58^{\mathrm{b}}$ \\
\hline 72 & $\begin{array}{l}0.440 \\
(0.01)\end{array}$ & $\begin{array}{l}0 \cdot 210 \\
(0.03)\end{array}$ & $S$ & $\begin{array}{c}2.30 \\
(0.02)\end{array}$ & 140 & $20-25$ & R-17 & 7 & 22 \\
\hline
\end{tabular}

*ele not determined; ${ }^{a}$ reaction was carried out in DMSO; ${ }^{b}$ attempts to get optically active form in both one-step and two step processes failed

prochiral and racemic substrates (scheme 7). The results are summarized in table 6. In general, using one-step procedure, products whenever solid could be obtained in $90 \%$ ele by repeated recrystallization; however the overall chemical yield was always less when compared with yield in two-step process. Also one major drawback of the one-step process was the need to use the chiral auxiliary in equivalent molar amount.

\subsection{Mechanism of the one-pot process}

Two mechanisms may be considered for the above one-pot formation of S-11, S-14 and other related compounds. Taking the case of S-11, its formation may involve preferential formation of chiral enamine $\mathbf{7 4}$ from the reaction of $S$-proline with pro- $R$ carbonyl group of dione $\mathbf{6 4}$ followed by Michael addition on the $S i$ face with MVK to yield $S$-enamine $\mathbf{7 4}$ and $S$-enamonium $\mathbf{7 5}$ intermediates (scheme 8). The intermediate $\mathbf{7 5}$ can be visualized as getting transformed to $\mathbf{S - 1 1}$ by more than one pathway.

It was of interest to determine if NMR evidence for the intermediates $\mathbf{7 4}$ or $\mathbf{7 5}$ could be obtained. Equivalent amounts of 2-methyl-1,3-cyclopentane dione $\mathbf{6 4}$ and $S$-proline were mixed together in DMSO- $d_{6}$, and allowed to stand for 3-4 h. Distilled methyl vinyl ketone (1 equiv.) was the added. ${ }^{13} \mathrm{C}$ NMR revealed that the initially insoluble proline forms a soluble complex with the 2-methyl-1,3-cyclopentane dione $\mathbf{6 4}$ and then reacts with MVK. Immediately after the addition of MVK, signals are seen for trione $\mathbf{1}$, ketol $\mathbf{8}$, the soluble proline-dione complex $\mathbf{6 7}$ and unreacted MVK. After $3 \mathrm{~h}$, the formation of ketol $\mathbf{8}$ is complete with no trace of MVK, trione $\mathbf{1}$ or the proline complex. Continued 


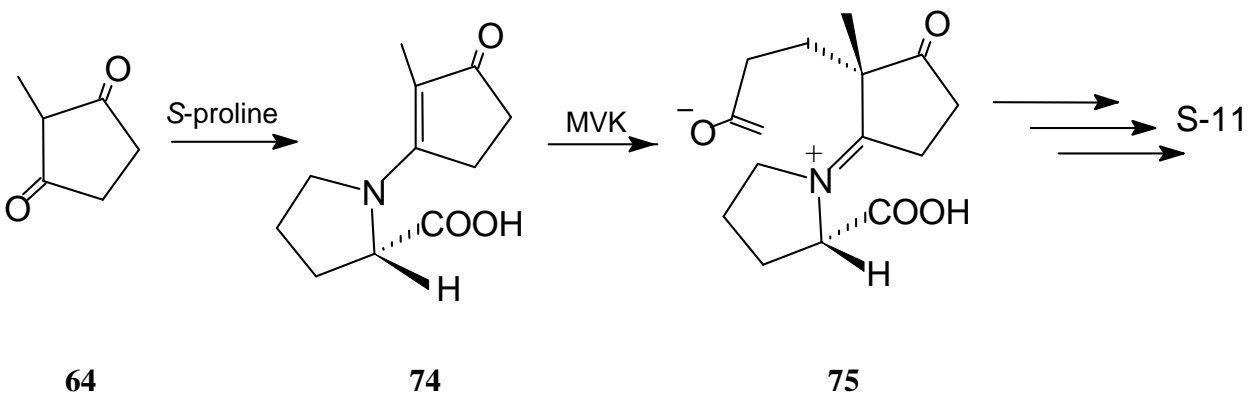

Scheme 8. Mechanism of the one-pot process.

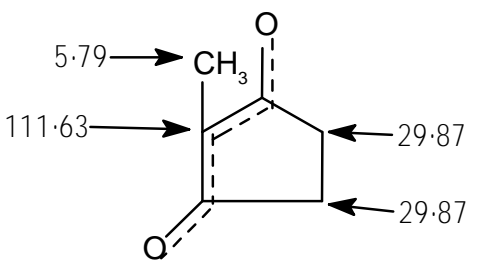

64

standing (up to $68 \mathrm{~h}$ ) shows mainly ketol $\mathbf{8}$ with trace of enone S-11. There was no evidence for the formation of enamine intermediate $\mathbf{7 4}$ or enammonium intermediate $\mathbf{7 5}$.

Evidently, the soluble proline complex 67 gives Michael adduct $\mathbf{1}$ directly in situ; this adduct then cyclized to ketol $\mathbf{8}$.

The proline complex with 2-methyl-1,3-cyclopentane dione 67 in DMSO- $d_{6}$ has the ${ }^{13} \mathrm{C}$ signals indicated.

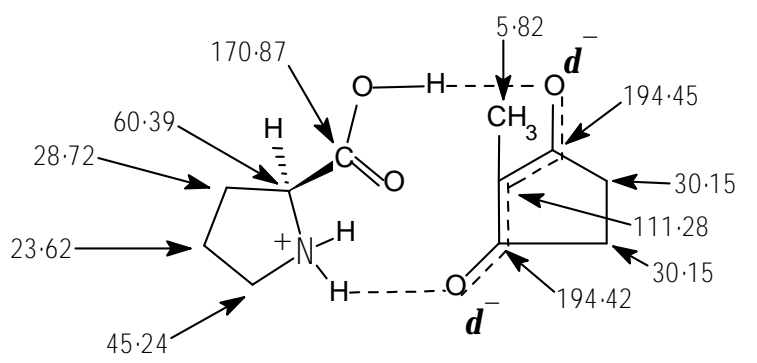

67

The one-step with 2-methyl-1,3-cyclohexane dione $\mathbf{7 0}$ was similarly monitored by taking ${ }^{13} \mathrm{C}$ NMR spectra at regular intervals over a period of $22 \mathrm{~h}$. 2-Methyl-1,3cyclohexane dione $70(0.25 \mathrm{mmol})$, in $0.5 \mathrm{~mL}$ of DMSO- $d_{6}$ showed carbon signals at $\delta 7 \cdot 26,21 \cdot 59,33 \cdot 54$ and 109.66. The absence of ketone carbonyl revealed that the 1,3dione $\mathbf{7 0}$ mostly exists in enol form. On adding $S$-proline to the dione 70, it forms a soluble proline-1,3-dione complex whose carbon signals are shown in the structure $\mathbf{6 8}$. 
Even after $5 \mathrm{~h}$, there was no change in the spectrum of the mixture indicating the formation of a stable complex between dione $\mathbf{7 0}$ and $S$-proline. Such a complex 68 automatically ruled out the formation of any enamine derivative. Distilled MVK $(0.25 \mathrm{mmol})$ was added to the above mixture and the reaction was monitored by taking ${ }^{13} \mathrm{C} \mathrm{NMR}$ spectrum at intervals of $15 \mathrm{~min}$ in the initial stages of reaction and later on every two hours towards the end of the reaction. Immediately after the addition of MVK, carbon signals are seen for trione 4, strong signals for the proline-1,3-dione complex $\mathbf{6 8}$ and MVK. After $3.5 \mathrm{~h}$, enedione $\mathbf{S - 1 4}$ starts showing up weak signals at $\delta 124.96$ and 166. After $22 \mathrm{~h}$, one observes signals for diketones $\mathbf{S - 1 4}$ along with very weak signals for dienamine 69 and MVK. Evidently the trione $\mathbf{4}$ is the primary product formed in situ, undergoing cyclization as described earlier.

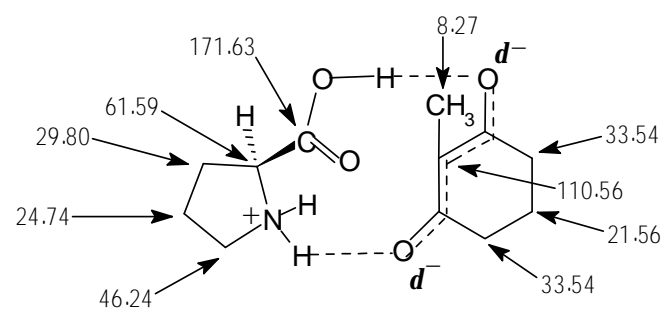

68

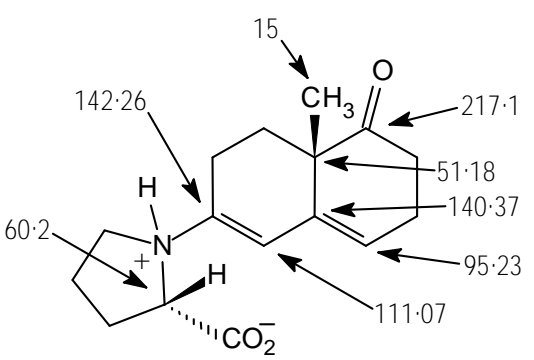

69

The above mechanism, though demonstrated for the one-step process carried out in DMSO, is probably also followed in the reaction carried out without solvent, since $S$ proline is practically insoluble in anhydrous DMSO.

\section{Mechanism of enantioselective annulation}

The enantioselective cyclization of both prochiral triones and racemic tricarbonyl compounds to optically active enediones must involve kinetic resolution. On the basis of the currently accepted enamine mechanism, one of the distereoisomeric enamine intermediates may cyclize faster than the other leading to an excess of one enantiomer. For example, enamine 55-SR may be more reactive than 55-SS and cyclize faster to give an excess of enantiomeric product. 


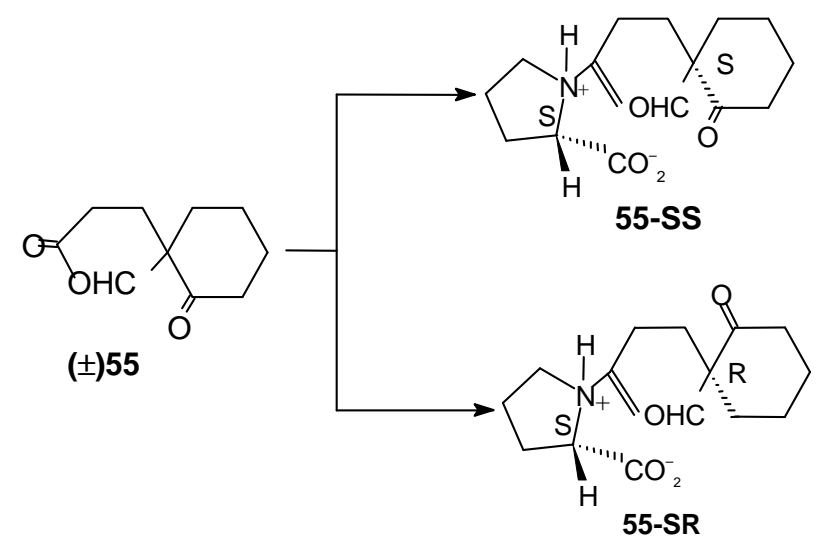

In the case of prochiral triones like $\mathbf{1}$, the chiral enamines intermediate may be reacting faster with the pro- $R$ carbonyl of the ring - leading to excess of ketol, $\mathbf{8}$.

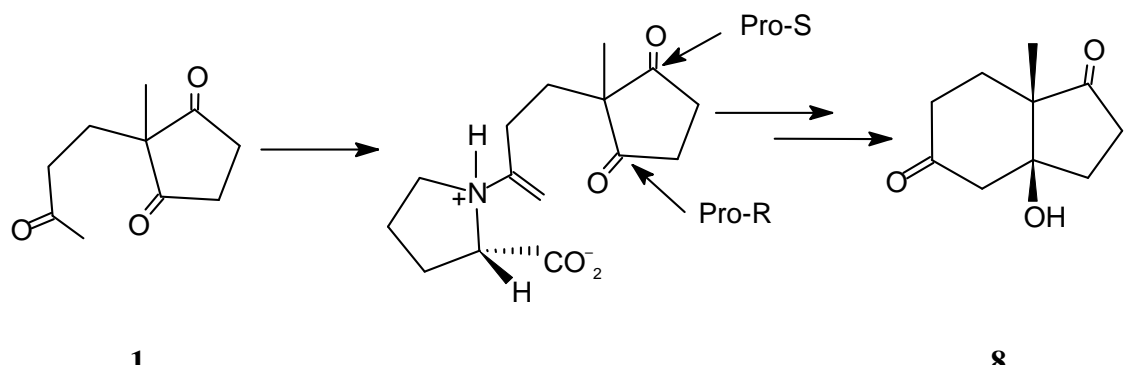

However, spectroscopic evidence has been obtained which rules out the enamine mechanism for the above type of asymmetric cyclization. Instead, a template mechanism ${ }^{16}$ involving protonation and deprotonation of the triketone $\mathbf{1}$ on the surface of $S$-proline crystal has been proposed. The hydrogen-bonded complexes of $S$-proline with pro- $S$ and pro- $R$ carbonyl groups of $\mathbf{1}$ may differ in energy and reactivity leading to chiral discrimination.

Similarly with $( \pm)-\mathbf{5 5}, S$-proline can form diastereoisomeric hydrogen-bonded complexes 76 and 77. They differ in energy and reactivity and hence may lead to enantioselective cyclization of ( \pm )-55.

In summary, asymmetric synthesis of a series of annulated carbocycles using suitable chiral auxiliary in the absence of solvent has been achieved.

\section{Experimental}

\subsection{General considerations}

All melting point and boiling points are uncorrected. IR spectra were recorded on a Shimadzu FTIR 230. ${ }^{1} \mathrm{H}$ and ${ }^{13} \mathrm{C}$ NMR spectra were recorded in $\mathrm{CDCl}_{3}$ using TMS as an internal standard on a Jeol GX 400 spectrometer at $400 \mathrm{MHz}$ and $100 \cdot 4 \mathrm{MHz}$ 


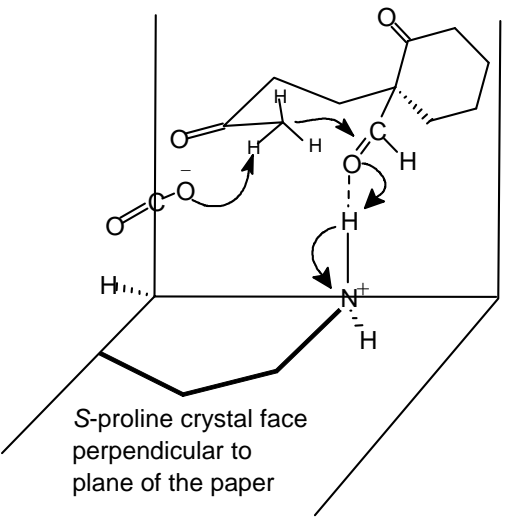

76

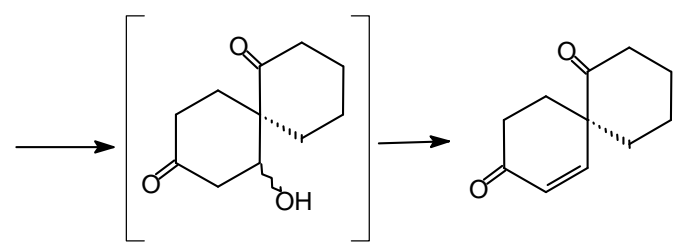

78

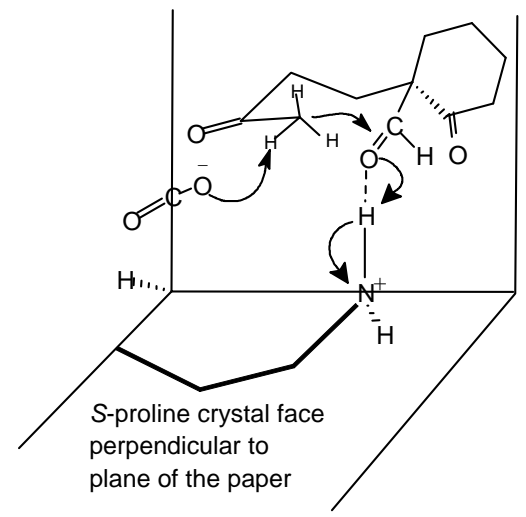

77

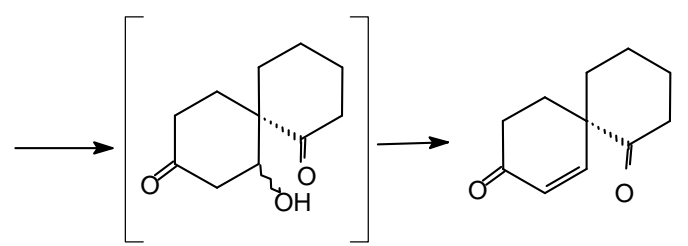

79
R-60

respectively. Mass spectra were recorded on a Finnigan MAT-8230 GC mass spectrometer. Enantiomeric excess of compounds S-59 and S-61 were determined using Chiralcel OJ/chiralcel AD chiral column using $n$-hexane/IPA (100:1) as an eluant with flow rate of $1.0 \mathrm{~mL} / \mathrm{min}$. Analytical data are given for unknown compounds only.

5.2 General procedure for reactions carried out in the absence of solvent-two-step synthesis using proline

In a dried round-bottomed flask, the Michael adduct was mixed with dried and powdered proline and allowed to stir under nitrogen atmosphere at room temperature. The progress of the reaction was monitored by following UV absorption of the characteristic of the product, whenever possible or after dehydration of ketol. After completion of the reaction, the entire reaction mixture was extracted with methylene chloride and the extract was washed (twice) with water to remove unreacted $S$-proline, dried 
over anhydrous $\mathrm{MgSO}_{4}$ and solvent evaporated under reduced pressure. The crude product was purified by flash column chromatography using $25 \%$ ethyl acetate:hexane as eluant.

5.3 General procedure for reactions carried out in the absence of solvent via two-step process using S-phenylalanine and d-camphorsulphonic acid

In an oven-dried round-bottomed flask, a mixture of Michael adduct $(0 \cdot 01 \mathrm{mmol}), S$ phenylalanine $(0.01 \mathrm{mmol})$ and $d$-camphorsulphonic acid $(0.005 \mathrm{mmol})$ was stirred in the absence of solvent at room temperature under nitrogen atmosphere for $24 \mathrm{~h}$. The mixture was heated initially at $40^{\circ} \mathrm{C}$ for $5 \mathrm{~h}$ then at $60^{\circ} \mathrm{C}$ for $12 \mathrm{~h}$, and finally at $74^{\circ} \mathrm{C}$ for $5 \mathrm{~h}$. The resulting viscous mass was powdered into cold aqueous $\mathrm{NaHCO}_{3}$ and extracted with methylene chloride $(100 \mathrm{~mL})$. Evaporation of solvent under reduced pressure followed by column chromatographic purification of the crude residue afforded the cyclized product.

\subsection{General procedure for one-step neat synthesis}

A $100 \mathrm{~mL}$ three-necked round-bottomed flask was charged with finely ground proline $(0.01 \mathrm{~mol})$ and 2 -alkyl-1,3-dione $(0.01 \mathrm{~mol})$, and mixed well for $1 \mathrm{~h}$ at room temperature under nitrogen atmosphere. Methyl vinly ketone $(0.015 \mathrm{~mol})$ was then added dropwise over $0.5 \mathrm{~h}$. The reaction mixture was stirred for an additional period and completion of reaction was monitored by taking UV spectrum in absolute ethanol. The resultant brown coloured viscous mass was then extracted with methylene chloride $(2 \times 100 \mathrm{~mL})$ and the extract thoroughly washed with distilled water $(2 \times 50 \mathrm{~mL})$. The organic layer was washed with brine and dried over anhydrous $\mathrm{MgSO}_{4}$. The solution was filtered and the filtrate concentrated under reduced pressure. The residue was chromatographed on flash silica gel using chloroform as eluant.

5.5 General procedure for one-step neat synthesis from 2-hydroxymethylene cycloalkanones using proline

A $100 \mathrm{~mL}$ three-necked round bottom flask containing magnetic stirrer was charged with $(0.01 \mathrm{~mol})$ of finely ground proline and 2-hydroxymethylene cycloalkanones $(0.01 \mathrm{~mol})$ and stirred at room temperature under nitrogen atmosphere for $2 \mathrm{~h}$. Freshly distilled methyl vinyl ketone $(0.012 \mathrm{~mol})$ was added drop wise to the above mixture over $0.5 \mathrm{~h}$. Stirring was continued for an additional period and completion of reaction was monitored by taking UV spectrum in absolute ethanol. The resultant brown coloured viscous mass was treated with methylene chloride $(150 \mathrm{~mL})$ and organic extract was washed with water $(2 \times 50 \mathrm{~mL})$ and brine, dried and the solvent removed under reduced pressure. The residue was purified by flash column chromatography using chloroform as elaunt.

\section{6 (+)-(8a-S)-(3'-oxobutyl)-3,4,8,8a-tetrahydro-1,5 (2H, 7H)-naphthalenedione, $\mathbf{S - 1 6}$}

Following the general procedure, compound S-16 was obtained as liquid by cyclization of tetraketone $\mathbf{6}$ in the absence of solvent. Yield: $48-55 \%$; IR $\left(\mathrm{CHCl}_{3}\right), \mathrm{cm}^{-1}: 1717,1705$ (saturated carbonyls); 1675 (conjugated carbonyl); 1605 (olefinic bond); ${ }^{1} \mathrm{H}$ NMR $\delta 5.78$ 
$\left(s, 1 \mathrm{H}\right.$, vinylic proton); $2 \cdot 18\left(s, 3 \mathrm{H},-\mathrm{COCH}_{3}\right), 1 \cdot 51-2 \cdot 82(\mathrm{~m}, 14 \mathrm{H}$, methylene protons), ${ }^{13} \mathrm{C}$ NMR $\delta 210 \cdot 66,209 \cdot 13,197 \cdot 92,165 \cdot 71,125 \cdot 45,50 \cdot 34,37 \cdot 35,36 \cdot 50,33 \cdot 32,31 \cdot 46$, 29.44, 29.08, 22.96, 22.66; $[\alpha]^{25}{ }_{\mathrm{D}}:+26 \cdot 2^{\circ}\left(\mathrm{C}, 3 \cdot 5\right.$, benzene); MS $(\mathrm{m} / \mathrm{z}): 234\left(\mathrm{M}^{+}\right)$; CD $(\mathrm{nm}): \quad\left(\theta_{\mathrm{obs}}\right)_{365}=-5 \times 10^{-3} \mathrm{deg} \quad(\mathrm{C}=0.005, \quad$ dioxane $), \quad\left(\theta_{\mathrm{obs}}\right)_{322}=+48 \times 10^{-3} \mathrm{deg}$ $(\mathrm{C}=0.005$, dioxane $),\left(\theta_{\text {obs }}\right)_{294}=+77 \times 10^{-3} \mathrm{deg}(\mathrm{C}=0.005$, dioxane $)$; Analysis: $\mathrm{C}_{14} \mathrm{H}_{18} \mathrm{O}_{3}$ requires $\mathrm{C}=71 \cdot 77, \mathrm{H}=7 \cdot 74 \%$; Found: $\mathrm{C}=71 \cdot 71, \mathrm{H}=7 \cdot 69 \%$.

5.7 (+)-(8aR)-3,4,8,8a-tetrahydro-8a-thiophenyl-5-methyl 1,6-(2H, 7H) naphthalenedione, $\boldsymbol{R}-25$

Following the general procedure the compound R-25 was obtained by asymmetric cyclization of prochiral trione 22. Yield: $41 \%$; m.p.: $106-108^{\circ} \mathrm{C}$; IR $(\mathrm{KBr}), \mathrm{cm}^{-1}$ : 1703 , $1665 ;{ }^{1} \mathrm{H}$ NMR $\delta 7 \cdot 20-7 \cdot 25,2 \cdot 03-3 \cdot 11(\mathrm{~m}, 10 \mathrm{H}$, methylene proton), $1.75(\mathrm{~s}, 1 \mathrm{H}$, vinylic methy); ${ }^{13} \mathrm{C}$ NMR $\delta 211 \cdot 33,196 \cdot 98,157 \cdot 52,130 \cdot 64,50 \cdot 11,36 \cdot 78,32 \cdot 67,29 \cdot 10,26 \cdot 24$, $22 \cdot 80,10 \cdot 39,129 \cdot 29,128.94,125 \cdot 47,123 \cdot 72 ;[\alpha]^{25}$ : $+33^{\circ}(\mathrm{C}, 2$, chloroform $)$; MS $(\mathrm{m} / \mathrm{z})$ : $286\left(\mathrm{M}^{+}\right) ; \mathrm{CD}(\mathrm{nm}):\left(\theta_{\mathrm{obs}}\right)_{243}=-2 \cdot 15 \times 10^{-3} \mathrm{deg} \quad(\mathrm{C}=0.005$, dioxane); Analysis: $\mathrm{C}_{17} \mathrm{H}_{18} \mathrm{O}_{2} \mathrm{~S}$ requires $\mathrm{C}=71 \cdot 28, \mathrm{H}=6 \cdot 33 \%$, Found: $\mathrm{C}=71 \cdot 34, \mathrm{H}=6 \cdot 28 \%$.

\section{8 (+)-(9aS)-propargyl-4-methyl-1,2,3,9-tetrahydrofluorene-3,9-dione, S-30}

Following the general procedure the compound S-30 was obtained by asymmetric cyclization of prochiral trione 27. Yield: $56 \%$; m.p.: $131-133^{\circ} \mathrm{C}$; IR $(\mathrm{KBr}), \mathrm{cm}^{-1}: 1725$ (saturated carbonyl), 1682 (conjugated carbonyl); 1602 (olefinic bond). ${ }^{1} \mathrm{H}$ NMR $\delta 7 \cdot 52-$ $7.94\left(m, 4 \mathrm{H}\right.$, aromatic protons), $2.62\left(d, J=2 \mathrm{~Hz},-\mathrm{CH}_{2}-\mathrm{C} \equiv \mathrm{CH}\right) ; 2 \cdot 12-2.60(m, 4 \mathrm{H}$, methylene protons); $1.92\left(t, J=2 \mathrm{~Hz}, 1 \mathrm{H}, \underline{\mathrm{HC}} \equiv \mathrm{C}-\mathrm{CH}_{2}\right) ; 1.82(s, 3 \mathrm{H}$, vinylic methyl); ${ }^{13} \mathrm{C}$ NMR $\delta 201.59,197.95,159.56,144.97,136.17,135.60,132.53,124.50,122.96$, $119 \cdot 44,78 \cdot 18,73 \cdot 31,50 \cdot 27,33 \cdot 37,26 \cdot 11,25 \cdot 74,20 \cdot 36 ;[\alpha]^{25}{ }_{\mathrm{D}}:+33^{\circ}(\mathrm{C}, 3 \cdot 1$, chloroform); $\mathrm{MS}(\mathrm{m} / \mathrm{z}): 250\left(\mathrm{M}^{+}\right) ; \mathrm{CD}(\mathrm{nm}):\left(\theta_{\mathrm{obs}}\right)_{285}=+3.3 \times 10^{-3} \mathrm{deg} \quad(\mathrm{C}=0.009$, dioxane) $\left(\theta_{\text {obs }}\right)_{340}=-0 \cdot 140 \times 10^{-3} \mathrm{deg}\left(\mathrm{C}=0 \cdot 009\right.$, dioxane); Analysis: $\mathrm{C}_{17} \mathrm{H}_{14} \mathrm{O}_{2}$ requires $\mathrm{C}=81 \cdot 58, \mathrm{H}=5 \cdot 63 \%$, Found: $\mathrm{C}=81 \cdot 56, \mathrm{H}=5.66 \%$.

\section{9 (+)-(7aS)-1,5-dioxo-methyl-7a-ethyl-2,3,5,6,7a, hexahydroindene $\mathbf{S}-22 \boldsymbol{a}$}

Following general procedure, the compound S-22a was obtained as a liquid from prochiral trione 19 in solvent-free condition. Yield: 55\%; IR $\left(\mathrm{CHCl}_{3}\right), \mathrm{cm}^{-1}$ : 1739 (saturated carbonyls); 1670 (conjugated carbonyl); 1608 (olefinic bond); ${ }^{1} \mathrm{H}$ NMR $\delta$ 1.91-2.92 ( $m, 10 \mathrm{H}$ methylene protons); 1.82 ( $\mathrm{s}, 3 \mathrm{H}$, vinylic methyl); 0.99 ( $t, 3 \mathrm{H}$, $\left.-\mathrm{CH}_{3} \mathrm{CH}_{2}-\right)$; ${ }^{13} \mathrm{C}$ NMR $\delta 216 \cdot 44,197 \cdot 44,162 \cdot 78,129 \cdot 49,52 \cdot 29,35 \cdot 17,32 \cdot 11,27 \cdot 21$, 24.86, 24.38, 10.35, 8.60; $[\alpha]_{\mathrm{D}}^{25}:+189^{\circ}\left(\mathrm{C}, 1.4\right.$, benzene); MS $(\mathrm{m} / \mathrm{z}): 192\left(\mathrm{M}^{+}\right)$; CD $(\mathrm{nm}): \quad\left(\theta_{\text {obs }}\right)_{294}=+2.1 \times 10^{-3} \mathrm{deg} \quad(\mathrm{C}=0.006, \quad$ dioxane $), \quad\left(\theta_{\text {obs }}\right)_{245}=-2.4 \times 10^{-3} \mathrm{deg}$ $\left(\mathrm{C}=0.006\right.$, dioxane); Analysis: $\mathrm{C}_{12} \mathrm{H}_{16} \mathrm{O}_{2}$ requires $\mathrm{C}=74.97, \mathrm{H}=8.38 \%$, Found: $\mathrm{C}=74.91, \mathrm{H}=8.31 \%$.

\subsection{0 (+)-4R-ethyl-4-acetyl-3-methyl-2-cyclohexanone, $\boldsymbol{R}-48$}

Following the general procedure, the compound $\mathbf{R - 4 8}$ was prepared as a liquid by asymmetric cyclization of acyclic prochiral trione 47. Yield: $45 \%$; IR $\left(\mathrm{CHCl}_{3}\right), \mathrm{cm}^{-1}$ : 1705 (saturated carbonyl); 1675 (conjugated carbonyl); 1615 (olefinic bond); ${ }^{1} \mathrm{H}$ NMR 
$\delta 6.01\left(s, 1 \mathrm{H}\right.$, vinylic proton); $2.28\left(s, 3 \mathrm{H},-\mathrm{COCH}_{3}\right), 1.92\left(s, 3 \mathrm{H}, \beta\right.$-vinylic $\left.-\mathrm{CH}_{3}\right), 1.82-$ $2.52\left(m, 6 \mathrm{H}\right.$, methylene protons), $0.98\left(t, 3 \mathrm{H}, \mathrm{CH}_{3} \mathrm{CH}_{2}-\right) ;{ }^{13} \mathrm{C}$ NMR $\delta 207.93,197.23$, $160 \cdot 83,129.55,56 \cdot 76,34 \cdot 55,30 \cdot 74,28 \cdot 19,26 \cdot 35,20 \cdot 84,8.53 ;[\alpha]_{D}^{25}:+9^{\circ}(C, 3 \cdot 1$, benzene); $\mathrm{MS}(\mathrm{m} / \mathrm{z}): 180\left(\mathrm{M}^{+}\right)$; Analysis: $\mathrm{C}_{11} \mathrm{H}_{16} \mathrm{O}_{2}$ requires $\mathrm{C}=73.29, \mathrm{H}=8.95 \%$; Found: $\mathrm{C}=73 \cdot 31, \mathrm{H}=8 \cdot 99 \%$.

\subsection{1 (+)-1S-cyclohex-2-ene spirocyclopentane-2,4'-dione, S-59}

Following the general procedure, the compound $\mathbf{S - 5 9}$ was obtained as a liquid by cyclization of $( \pm)-\mathbf{5 4}$ in the neat. Yield: $39-53 \%$; IR $\left(\mathrm{CHCl}_{3}\right), \mathrm{cm}^{-1}: 1730$ (saturated carbonyl); 1680 (conjugated carbonyl); 1600 (olefinic bond); ${ }^{1} \mathrm{H}$ NMR $\delta 6.89(d$, $J=10 \mathrm{~Hz}, 1 \mathrm{H}, \beta$-vinylic proton), $5.58(d, J=10 \mathrm{~Hz}, 1 \mathrm{H}, \alpha$-vinylic proton); $1.22-2.41$ ( $m, 10 \mathrm{H}$, methylene protons); ${ }^{13} \mathrm{C}$ NMR $\delta 203 \cdot 85,198 \cdot 81,151 \cdot 10,129 \cdot 61,52 \cdot 15,34 \cdot 37$, $33.43,30.14,26.42$ and $25.40 ;[\alpha]^{25}$ : $+4.8^{\circ}(\mathrm{C}, 2.9$, methanol); ele $29.04 \% \mathrm{MS}(\mathrm{m} / \mathrm{z})$ : $164 \quad\left(\mathrm{M}^{+}\right) ; \quad \mathrm{CD} \quad(\mathrm{nm}): \quad\left(\theta_{\mathrm{obs}}\right)_{310}=+22.4 \times 10^{-3} \quad \operatorname{deg} \quad(\mathrm{C}=0.005, \quad$ dioxane $)$, $\left(\theta_{\text {obs }}\right)_{277}=+11.4 \times 10^{-3} \mathrm{deg}(\mathrm{C}=0.005$, dioxane $)$; Analysis: $\mathrm{C}_{10} \mathrm{H}_{12} \mathrm{O}_{2}$ requires $\mathrm{C}=73.15$, $\mathrm{H}=7 \cdot 37$; Found: $\mathrm{C}=73 \cdot 50, \mathrm{H}=7 \cdot 41 \%$.

\subsection{2 (+)-1S-cyclohex-2-ene spirocycloheptane-2,4'-dione, $\mathbf{S - 6 1}$}

Following the general procedure, the compound $\mathbf{S - 6 1}$ was obtained by cyclization of $( \pm)$ 56 in solvent-free condtion. Yield: 53-55\%; IR $\left(\mathrm{CHCl}_{3}\right), \mathrm{cm}^{-1}: 1710$ (saturated carbonyl); 1690 (conjugated carbonyl); 1600 (olefinic bond); ${ }^{1} \mathrm{H}$ NMR $\delta 6.91(d, J=10.5 \mathrm{~Hz}, 1 \mathrm{H}$, $\beta$-vinylic proton), $6.05(d, J=10.5 \mathrm{~Hz}, 1 \mathrm{H}, \alpha$-vinylic proton); $1.40-2.85(m, 10 \mathrm{H}$, methylene protons); ${ }^{13} \mathrm{C}$ NMR $\delta 210.99,197 \cdot 01,150 \cdot 32,128.34,52 \cdot 64,39 \cdot 38,35.48$, $33 \cdot 27,30 \cdot 79,29 \cdot 43,25 \cdot 79,23 \cdot 71 ;[\alpha]^{25}$ : $+1 \cdot 42^{\circ}(\mathrm{C}, 2$, methanol); ele $4 \cdot 2 \% \mathrm{MS}(\mathrm{m} / \mathrm{z})$ : $192 \quad\left(\mathrm{M}^{+}\right) ; \quad \mathrm{CD} \quad(\mathrm{nm}): \quad\left(\theta_{\mathrm{obs}}\right)_{313}=-2.8 \times 10^{-3} \quad \operatorname{deg} \quad(\mathrm{C}=0.005, \quad$ dioxane $)$, $\left(\theta_{\text {obs }}\right)_{261}=+10.1 \times 10^{-3} \operatorname{deg}(\mathrm{C}=0.005$, dioxane $),\left(\theta_{\text {obs }}\right)_{227}=+6.5 \times 10^{-3} \operatorname{deg}(\mathrm{C}=0.005$, dioxane); Analysis: $\mathrm{C}_{12} \mathrm{H}_{16} \mathrm{O}_{2}$ requires $\mathrm{C}=74.97, \mathrm{H}=8.39 \%$; Found: $\mathrm{C}=75.01$, $\mathrm{H}=8.41 \%$.

\subsection{3 (+)-1S-cyclohex-2-ene spirocyclooctane-2,4'-dione, $\mathbf{S - 6 2}$}

Following the general procedure, the compound $\mathbf{S - 6 2}$ was obtained as a liquid by cyclization of $( \pm)-57$ in the neat. Yield: 52-61\%; IR $\left(\mathrm{CHCl}_{3}\right), \mathrm{cm}^{-1}: 1712$ (saturated carbonyl); 1695 (conjugated carbonyl); 1600 (olefinic bond); ${ }^{1} \mathrm{H}$ NMR $\delta 6.89(d$, $J=10.25 \mathrm{~Hz}, 1 \mathrm{H}, \beta$-vinylic proton), $6.09(d, J=10.25 \mathrm{~Hz}, 1 \mathrm{H}, \alpha$-vinylic proton); 1.25 $2.64\left(m, 16 \mathrm{H}\right.$, methylene protons); ${ }^{13} \mathrm{C}$ NMR $\delta 215 \cdot 88,198 \cdot 57,150 \cdot 25,129.92,52 \cdot 36$, $37.20,33.90,33.50,30 \cdot 10,30 \cdot 05,29.61,25 \cdot 74,24 \cdot 46 ;[\alpha]^{25}:+29 \cdot 15^{\circ}(\mathrm{C}, 12 \cdot 8$, benzene); MS $(\mathrm{m} / \mathrm{z}): 206\left(\mathrm{M}^{+}\right) ; \mathrm{CD}(\mathrm{nm}):\left(\theta_{\text {obs }}\right)_{304}=+87.3 \times 10^{-3} \operatorname{deg}(\mathrm{C}=0.006$, dioxane), $\left(\theta_{\text {obs }}\right)_{343}=-14.7 \times 10^{-3} \operatorname{deg}\left(\mathrm{C}=0.006\right.$, dioxane); Analysis: $\mathrm{C}_{13} \mathrm{H}_{18} \mathrm{O}_{2}$ requires $\mathrm{C}=75 \cdot 68, \mathrm{H}=8.79 \%$; Found: $\mathrm{C}=75 \cdot 59, \mathrm{H}=8.83 \%$.

\section{Acknowledgement}

We thank the DST and CSIR for financial assistance. We also acknowledge the help of Mr Mikio Takahashi, General Manager, Jasco International, Tokyo, Japan, for chiral HPLC studies. 


\section{References}

1. Jung M E 1976 Tetrahedron 32 3; (b) Gawley R E 1976 Synthesis 777

2. Rajagopal D, Rajagopalan K and Swaminathan S 1996 Tetrahedron: Asymmetry 82189

3. Verma R S 1999 Green Chem. 243

4. (a) Toda F and Takana K 2000 Chem. Rev. 100 391; (b) Metzger J O 1998 Angew. Chem., Int. Ed. Engl. 37 21; (c) Dittmer D C 1997 Chem. Ind. 6 779; (d) Toda F 1995 Acc. Chem. Res. 28 480; Toda F 1993 Synlett. 5303

5. (a) Corey E J, Ohno M, Paul A V and Mitra R B 1964 J. Am. Chem. Soc. 86 478; (b) Gutzwiller J, Meier W and Fürst A 1977 Helv. Chim. Acta 602258

6. (a) Rupper J, Eder V and Weichert R 1973 Chem. Ber. 106 3636; (b) Das J, Dickinson R A, Kakushima M, Kingston G M, Reid G R, Sato Y and Valenta Z 1984 Can. J. Chem. 621103

7. (a) Hajos Z G and Parrish D R 1974 J. Org. Chem. 39 1615; (b) Hajos Z G and Parrish D R 1985 Org. Syn. 63 26; (c) Eder U, Sauer G and Weichert R 1977 Angew. Chem., Int. Ed. Engl. 10 496; (d) Bühschacher P and Fürst A 1985 Org. Syn. 6337

8. (a) Hagiwara H and Uda H 1988 J. Org. Chem. 53 2308; Banerjee D K, Kasturi T R and Sarkar S 1983 Proc. Indian Acad. Sci. (Chem. Sci.) 92181

9. Takano S, Kasahara C and Ogasawara K 1981 J. Chem. Soc., Chem. Commun. 635

10. Chinnakali K, Fun H K, Rajagopal D and Swaminathan S 1999 Acta Cryst. $\mathbf{C 5 5} 772$

11. Lewicka-Piekut S and Okamura W H 1980 Synth. Commun. 10415

12. Chinnakali K, Fun H K, Rajagopal D, Swaminathan S and Sriraghavan K 1999 Acta Cryst. C55 1135

13. Terashima S, Sato S and Koga K 1988 Tetrahedron Lett. 363469

14. Eaton P E and Jobe P G Synthesis 10796

15. Narayanan R and Swaminathan S 1990 Indian J. Chem. B29 1401

16. Rajagopal D, Moni M S, Subramanian S and Swaminathan S 1999 Tetrahedron: Asymmetry 10 1631 